\title{
ANALISIS STRUKTUR DAN KEBAHASAAN BUKU MOHAMMAD HATTA DAN RELEVANSINYA DALAM PEMBELAJARAN MENULIS TEKS BIOGRAFI DI KELAS X KURIKULUM 2013
}

\author{
Ida Bagus Mas Permana Wibawa ${ }^{1}$, I Made Sutama², I Nyoman Yasa ${ }^{3}$ \\ Prodi Pendidikan Bahasa Indonesia, Jurusan Bahasa Sastra Indonesia dan \\ Daerah, \\ Universitas Pendidikan Ganesha \\ Singaraja, Indonesia
}

e-mail:\{guslilikjunior@gmail.com¹, imadesutamaubd@gmail.com²,

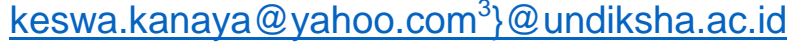

\begin{abstract}
ABSTRAK
Penelitian ini bertujuan untuk menganalisis struktur dan kebahasaan buku yang berjudul Mohammad Hatta serta relevansinya terhadap pembelajaran menulis teks biografi di kelas X kurikulum 2013. Penelitian ini menggunakan rancangan penelitian deskriptif kualitatif. Subjek penelitian ini adalah buku Mohammad Hatta terbitan C-Klik Media sedangkan objek penelitian ini adalah struktur dan kebahasaan buku Mohammad Hatta serta relevansinya terhadap pembelajaran menulis teks biografi kelas X Kurikulum 2013. Data dikumpulkan dengan metode dokumentasi. Analisis data dilakukan dengan cara menginterpretasikan data dengan kata-kata dan penarikan kesimpulan. Adapun hasil penelitian, yaitu (1) Dari segi struktur, buku Mohammad Hatta mengandung keseluruhan stuktur teks biografi meliputi, orientasi, peristiwa dan masalah, serta reorientasi, (2) Buku Mohammad Hatta juga mengandung kebahasaan teks biografi meliputi, kata kerja, rujukan kata, kata hubung serta kata yang menunjukkan peristiwa, waktu, dan tempat, (3) Buku Mohammad Hatta memiliki relevansi dalam pembelajaran menulis teks biografi.
\end{abstract}

Kata Kunci : kebahasaan, struktur, relevansi, buku Mohammad Hatta

\begin{abstract}
This research aimed to analyze the structure and language of the book entitled Mohammad Hatta and its relevance towards writing biography text in X grade class in curriculum 2013. The current study used descriptive qualitative design. The subject of the study was Mohammad Hatta book which published by C-Klik Media meanwhile the object of the study was the structure and language of the book entitled Mohammad Hatta and its relevance towards learning writing biography text in X grade class in Curriculum 2013. The data was collected by using documentation method. The data was analyzed by explaining the data with words and also by drawing conclusion. There are several results of the study were, (1) From the structural aspect, the book contained whole structure of biography text which covered, orientation, incident, problem, and reorientation, (2) The book also contained language of biographycal text which covered, verb, word reference, conjunction and some word that indicate the incident, time, and place, (3) The book has relevance in learning writing biographycal text.
\end{abstract}

Keywords: language, structure, relevance, Mohammad Hatta book 
Volume : 9 Nomor: 2, Agustus 2019

P-ISSN : 2614-4743 (cetak) dan e-ISSN : 2614-2007 (online)

\section{PENDAHULUAN}

Pembelajaran Bahasa Indonesia memiliki empat aspek keterampilan berbahasa yang meliputi menyimak, berbicara, membaca, dan menulis (Tarigan, 2008:1). Menulis sangatlah penting bagi pendidikan karena memudahkan para pelajar untuk berfikir, dan menulis juga dapat membantu setiap orang untuk menjelaskan apa yang ada di dalam pikiran. Hasil dari hal tersebut adalah sebuah teks yang nantinya akan dibaca oleh orang lain.

Sejalan dengan hal tersebut Kurikulum 2013 adalah kurikulum yang berbasis teks. Untuk mata pelajaran bahasa Indonesia Kurikulum 2013 menggunakan teks sebagai sarana pembelajaran (Priyatni, 2014:67). Mata pelajaran untuk bahasa Indonesia dalam kurikulum 2013 hampir semua berbasis teks. Teks dapat dikelompokkan menjadi dua kategori besar (genre), yaitu genre sastra dan genre faktual (Anderson, 1797 dalam Priyatni, 2014:66). Pada jenjang SMA/SMK terdapat 7 jenis teks, yaitu (1) teks hasil observasi, (2) teks negosiasi,(3) teks eksposisi, (4) teks anekdot, (5) teks puisi, (6) teks cerita rakyat(7) teks cerita biografi(Permendikbud No. 68 tahun 2013 dalam Priyatni 2014:68).

Dalam penelitian ini peneliti memilih teks biografi untuk dikaji. Hal tersebut dilakukan karena menulis teks biografi sangat sering tidak dianggap penting. Padahal segala macam teks yang diajarkan memiliki nilainya sendiri.Karena kurikulum 2013 berbasis teks, maka peneliti tertarik mengkaji menulis teks biografi dengan sumber alternatif selain buku pedoman guru. Pembelajaran menulis teks biografi merupakan salah satu materi yang terdapat dalam silabus Kurikulum 2013 kelas X semester genap.

Proses penyusunan teks ini pun tidak sembarangan melainkan mencari data-data yang akurat. Menurut Susanto (2014: 217-219), struktur teks biografi sebagai berikut: (1) Orientasi, merupakan bagian awal yang menceritakan masa kecil serta tempat dan tanggal lahir tokoh, (2) Peristiwa atau masalah, dalam teks biografi pristiwa atau masalah dapat ditulis dalam beberapa paragraf, dan berisi peristiwa hebat dan menakjubkan yang dialami tokoh, (3) Reorientasi, merupakan penutup yang berisi opini Penulis buku dan biasanya bersifat opsional (bisa ada atau tidak). Namun terkadang hambatan siswa dalam menulis teks biografi adalah kurangnya pemahaman siswa terhadap struktur dan kebahasaan teks biografi.

Berdasarkan hal tersebut penulis menawarkan sebuah buku yang berjudul "Mohammad Hatta" yang diharapkan mampu membantu siswa dalam menulis teks biografi yang baik dan benar. Buku berjudul "Mohammad Hatta" ini dikarang oleh Anom Whani Wicaksana. Buku Mohammad Hatta diterbitkan tahun 2018 di C-Klik Media. Buku ini terdiri atas 20 BAB yang menceritakan seluruh kehidupan Mohammad Hatta mulai dari beliau kecil hingga akhir hayatnya. dalam satu $B A B$ buku ini, ada sepenggal kisah inspiratif yang bisa dijadikan pedoman hidup bagi pembacanya. Peneliti menjadikan buku ini sebagai salah satu sumber belajar menulis teks biografi di sekolah. Hal tersebut bertujuan untuk lebih mengembangkan sumber belajar siswa di sekolah.

Fokus permasalahan penelitian ini, yaitu struktur berupa (orientasi, kejadian penting, dan reorientasi) dan ciri kebahasaan berupa (kata ganti, kata kerja, kata sifat, kata hubung (konjungsi), kata depan, dan kata keterangan). Peneliti merasa perlu menganalisis struktur dan kebahasaan buku Mohammad Hatta karena faktanya siswa mengalami kesulitan pada struktur dan kebahasaan teks biografi. Pada saat siswa menulis teks biografi struktur dan kebahasaan teks biografi hanya dipandang sebelah mata. Peneliti akan menjadikan buku ini sebagai bahan ajar menulis teks biografi. Karena hal tersebut peneliti mengkaji struktur dan kebahasaan buku ini agar relevan dijadikan bahan ajar pembelajaran menulis teks biografi dan membantu siswa untuk menulis teks biografi dengan baik dan benar.

Hasil observasi awal di SMK N 1 Sukasada, masalah yang paling utama 
yang dialami siswa adalah dari segi kebahasaan. Salah seorang guru di sana bernama Bapak Dewa Carma mengatakan bahwa dari tahun ke tahun siswa tidak mampu menulis teks biografi dengan baik dan benar. Kendalanya adalah siswa kurang memahami struktur dan kebahasaan teks biografi. Selain itu, siswa juga kurang mampu mengembangkan topik. Pada bagian struktur, siswa tidak mampu menempatkan atau mengurutkan struktur teks biografi dengan benar. Pada bagian kebahasaan, kosa kata atau diksi yang digunakan siswa masih sangat monoton. Faktor lain yang menjadi penghambat siswa adalah kurangnya buku panduan atau pedoman untuk menulis teks biografi. Berdasarkan hal tersebut, peneliti menggunakan buku Mohammad Hatta sebagai salah satu sumber alternatif belajar siswa menulis teks biografi.

Peneliti memilih buku Mohammad Hatta sebagai buku model untuk pembelajaran menulis teks biografi karena (1) Rendahnya pemahaman tentang struktur dan kebahasaan teks biografi yang baik dan benar. (2) Kurangnya pemahaman tentang cerita biografi. Hal tersebut dikarenakan rendahnya minat baca siswa terhadap buku biografi (3) Kurangnya sumber buku yang relevan untuk membantu memecahkan permasalahan dalam menulis teks biografi. (4) Adanya banyak pilihan teks selain teks biografi.

Berdasarkan hasil wawancara awal di SMK N 1 Sukasada dengan Bapak Dewa Carma sebagai guru bahasa Indonesia, dapat dianalisis bahwa siswa mengalami kesulitan dalam hal menulis, khususnya menulis teks biografi. Hambatan siswa yang utama terletak pada pengembangan ide tulisan dan selanjutnya terletak pada pemilihan diksi yang monoton. Dengan demikian, peneliti tertarik untuk melakukan penelitian yang berjudul "Analisis Struktur dan Kebahasaan Buku Mohammad Hatta dan Relevansinya dalam Pembelajaran Menulis Teks Biografi di Kelas X Kurikulum 2013".

\section{METODE PENELITIAN}

Penelitian ini mengkaji struktur dan kebahasaan dalam buku Mohammad Hatta dan relevansinya terhadap pembelajaran menulis teks biografi kelas $X$ kurikulum 2013. Oleh karena itu, rancangan penelitian yang digunakan adalah deskriptif kualitatif. Penelitian deskriptif dilakukan untuk mengumpulkan data mengenai struktur dan kebahasaan buku Mohammad Hatta, sedangkan penelitian kualitatif bersifat subjektif yang mendeskripsikan buku Mohammad Hatta.

Rancangan penelitian deskriptif ini dipilih karena rancangan penelitian ini mampu menggambarkan secara keseluruhan deskripsi mengenai struktur, kebahasaan, serta relevansi buku Mohammad Hatta. Subjek penelitian ini adalah buku Mohammad Hatta terbitan CKlik Media, tebal buku 202 halaman sedangkan objek penelitian ini adalah struktur dan kebahasaan buku Mohammad Hatta serta relevansinya terhadap pembelajaran menulis teks biografi kelas $X$ Kurikulum 2013.

Metode pengumpulan data yang digunakan adalah metode dokumentasi. Metode dokumentasi dipilih karena penelitian ini meneliti dokumen tertulis berupa buku Mohammad Hatta karya Anom Whani Wicaksana

Instrumen yang digunakan oleh peneliti berupa kartu data. Kartu data digunakan untuk mencatat teks penting yang berkaitan dengan struktur teks biografi dan kebahasaan teks biografi.

\section{HASIL DAN PEMBAHASAN}

Buku yang berjudul Mohammad Hatta ini adalah salah satu contoh buku biografi yang menceritakan perjalanan atau riwayat kehidupan seorang tokoh yang bernama Mohammad Hatta. Hal tersebut senada dengan pendapat Sukirno (2016: 55) Menyatakan bahwa biografi adalah tulisan yang isinya menceritakan atau mengisahkan kehidupan seseorang atau orang lain. Buku berjudul "Mohammad 
Volume : 9 Nomor: 2, Agustus 2019

P-ISSN : 2614-4743 (cetak) dan e-ISSN : 2614-2007 (online)

Hatta" ini dikarang oleh Anom Whani Wicaksana.

Hatta adalah sosok yang harus diteladani dilihat dari banyaknya prestasi yang beliau raih dan pengabdiannya terhadap bangsa Indonesia hingga diberikan gelar "Bapak Bangsa". Berdasarkan hal tersebut, penulis memilih kisah hidup tokoh Mohammad Hatta yang sangat inspiratif. Buku ini diterbitkan tahun 2018 di C-Klik Media. Buku ini terdiri atas 20 BAB yang menceritakan seluruh kehidupan Mohammad Hatta mulai dari beliau kecil hingga akhir hayatnya.

Dalam buku Mohammad Hatta terkandung struktur teks biografi meliputi orientasi, peristiwa dan masalah, serta reorientasi, dan kebahasaan teks biografi meliputi kata kerja, kata hubung, rujukan kata, serta peristiwa waktu dan tempat. Masing-masing cerita yang mengandung struktur teks biografi dan kebahasaan teks biografi diuraikan sebagai berikut.

Orientasi atau bagian pengenalan adalah gambaran awal tentang tokoh atau pelaku di dalam teks biografi Zabadi dan Sutejo (2013:42). Hal tersebut ada di dalam bab 1, bab 2, dan bab 3. Pada bab tersebut ditunjukkan tempat dan tanggal lahir dari Mohammad Hatta, kehidupan di keluarganya, serta perjalanan pendidikannya. Seperti yang tampak pada kutipan berikut.

"Pada 12 Agustus 1920, disebuah rumah kayu bertingkat dua di Desa Aur Tajungkang, Bukit Tinggi, pasangan suami istri sedang berbahagia. Sang istri Siti Saleha melahirkan seorang bayi laki-laki yang kemudian dinamai Muhammad Athar. Nama Athar berasal dari bahasa Arab, yang berarti "harum". Kelak kita mengenal namanya sebagai Mohammad Hatta"(Wicaksana, 2018:1)

Kutipan tersebut menunjukkan pengenalan awal tokoh yang terlahir di desa kecil yang bernama Desa Aur Tajungkang. Rumah yang bertingkat itu cukup luas bagi keluarga Hatta dan juga masih ada tempat bagi pelayan dan pembantu rumah tangga yang tinggal di dalam

Kutipan tersebut juga telah mencerminkan struktur teks biografi pertama yaitu orientasi. Namun orientasi dalam buku Mohammad Hatta tidak hanya sampai di sana melainkan lebih dari itu. Seperti kutipan lanjutan berikut.

"Athar adalah anak kedua bagi pasangan Mohammad Djamil dan Saleha. Anak pertama mereka, Rafiah, sudah terlebih dahulu lahir pada tahun 1900. Hatta memiliki garis darah dari dua keluarga terkemuka....". (Wicaksana, 2018:2)

Lanjutan kutipan tersebut menggambarkan kehidupan keluarga Mohammad Hatta. Hal tersebut baru segelintir pelajaran Hatta di masa kecilnya. Pelajaran hidup Hatta baru dimulai ketika Hatta mengenyam pendidikan dasar di Europeesche Lagere School (ELS), hal tersebut tampak pada kutipan berikut.

"Hatta lantas menempuh pendidikan dasar di Europeesche Lagere School (ELS), sekolah dasar khusus untuk anak-anak Belanda, di Bukit tinggi. Setiap pagi ia diantar ke sekolah dengan kereta bendi milik kakeknya. Di sekolah ia tergolong anak yang pandai, tekun, dan disiplin. la juga tak pernah absen datang ke surau Syehk Djambek setiap habis belajar di ELS". (Wicaksana, 2018:4)

Hatta terus melanjutkan pendidikannya dengan segala dukungan dari orang-orang disekitarnya walaupun harus pindah-pindah tempat tinggal. Hal tersebut tampak pada kutipan berikut.

"Pada tahun 1913, Hatta melanjutkan pendidikan ke MULO (Meer Uitgebreid Lagere Onderwijs) di Padang". (Wicaksana, 2018:6) 


$\begin{array}{lccc}\text { "Setamat } & \text { sekolah di } & \text { Padang, pada } \\ \text { pertengan Juni } & 1919 & \text { Hatta } \\ \text { melanjutkan studi } & \text { di } & \text { HBS". } \\ \text { (Wicaksana, 2018:7) } & & \end{array}$

"Setelah lulus dari HBS dengan nilai lulusan sangat tinggi, pada tahun 1921 Hatta ditawari beasiswa untuk belajar di Rotterdam School of Commerce, Belanda". (Wicaksana, 2018:7)

Kutipan tersebut menunjukkan kegigihan Hatta untuk belajar hingga mendapat tawaran untuk kuliah di Belanda. Seperti yang terdapat dalam kutipan berikut.

"Pada September 1921 Hatta mulai menjadi mahasiswa baru di Rotterdamse Handelshogeschool, sebuah sekolah ekonomi bergengsi". (Wicaksana, 2018:19)

Kutipan tersebut menunjukkan Hatta mengawali pendidikan tingginya di Belanda. Awalnya Hatta enggan pindah ke sekolah Belanda, karena dia takut kehilangan teman-teman sepermainan di sekolah, yang semuanya adalah anakanak bangsa sendiri.

Jadi, kutipan-kutipan di atas merupakan kalimat atau frase yang menunjukkan orientasi atau pengenalan awal pada buku biografi Mohammad Hatta. Orientasi pada buku Mohammad Hatta sudah mencangkup semua aspek yang dibutuhkan untuk menjelaskan struktur orientasi. Disebut orientasi, karena dari segi artinya, menurut Zabadi dan Sutejo (2013:42), orientasi diartikan sebagai gambaran awal kehidupan tokoh yang diangkat dalam sebuah teks biografi. Gambaran awal yang dimaksud yaitu, tempat atau tanggal lahir, kehidupan keluarga, dan kehidupan masa kecilnya.

Peristiwa dan masalah adalah bagian kejadian yang berisi penjelasan peristiwaperistiwa yang dialami oleh tokoh termasuk masalah yang dihadapinya dalam mencapai cita-citanya. Bagian ini terdapat pada BAB
4, BAB 5, BAB 6, BAB, BAB 8, BAB 9, dan $B A B$ 10. Peristiwa dan masalah yang dialami oleh Hatta dimulai dari semenjak ia lulus setelah kuliah di Belanda. Seperti yang terdapat dalam kutipan berikut.

"Sepulang dari Belanda pada Mei 1933, Hatta dan Soetan Sjahir membentuk PNI (Pendidikan Nasional Indonesia) atau PNI baru....". (Wicaksana, 2018:27)

Serangkaian peristiwa penting dalam hidup Hatta dimulai ketika ia selesai melaksanakan studinya di Belanda. Seperti yang terdapat dalam kutipan berikut.

"Pada Januari 1935 Hatta diasingkan ke Boven Digul di Papua". (Wicaksana, 2018:28)

Dengan diasingkannya Hatta di Boven Digul, Belanda setidaknya mampu membungkam suara aktivis yang secara keseluruhan digerakkan oleh Hatta dan Sjahrir.Seperti yang terdapat dalam beberapa kutipan berikut.

"Pada tahun 1936 Hatta menerima telegram yang mengatakan bahwa ia akan dipindahkan dari Boven Digul ke Banda Neira". (Wicaksana, 2018:37)

Selama 6 tahun Hatta dan Sjahrir diasingkan di dua tempat yang berbeda. Pada akhirnya mereka dipulangkan ke Jakarta. Seperti yang terdapat dalam beberapa kutipan berikut.

"Pada 31 Januari 1942 pemerintah kolonial Belanda memulangkan Hatta dan Sjahrir ke Jakarta". (Wicaksana, 2018:43)

Jepang mengajak Indonesia bekerja sama melalui Hatta dengan menawari Hatta jabatan penting jika bersedia. Hal tersebut terdapat dalam kutipan berikut.

"Hatta adalah orang pertama yang memberanikan diri untuk berdiskusi dengan Mayjen Harada agar tidak menjadikan Indonesia sebagai koloni Jepang tapi justru mengakui 
kemerdekaan Indonesia sebagai atas nama pesaudaraan di Asia". (Wicaksana, 2018:50)

Hatta mengambil keputusan yang kontroversial dan berani. Seperti yang terdapat dalam kutipan berikut.

"Sikap Hatta terhadap Jepang memang mengundang kontroversi di kalangan aktivis pergerakan". (Wicaksana, 2018:52)

Hatta selalu terlibat dalam peristiwa penting yang terjadi di Indonesia. Seperti yang terdapat dalam kutipan berikut.

"Pada Juni 1945, Badan Penyelidik Usaha Persiapan Kemerdekaan Indonesia (BPUPKI) membentuk panitia kecil yang disebut Panitia Sembilan". (Wicaksana, 2018:54)

Setelah tergabung dalam panitia sembilan yang dibentuk oleh BPUPKI, Hatta kembali tergabung dalam rombongan yang diundang ke Dalat, Vietnam untuk dilantik sebagai ketua PPKI. Seperti yang terdapat dalam kutipan berikut.

"Kemudian pada 9 Agustus 1945, Hatta bersama Soekarno dan Radjiman Wedyodiningrat diundang ke Dalat, Vietnam, untuk dilantik sebagai ketua PPKl". (Wicaksana, 2018:54)

Sungguh usaha yang tidak sia-sia, Hatta dan rekan-rekannya menuai hasil positif. Hasil yang mereka dan rakyat Indonesia tunggu-tunggu. Seperti yang terdapat dalam kutipan berikut.

"Dalam Pertemuan pada 12 Agustus 1945 Jendral Terauchi menyerahkan soal kemerdekaan kepada PPKI". (Wicaksana, 2018:54)

Kesempatan memerdekakan Indonesia pun muncul saat Hiroshima dan Nagasaki di bombardir oleh Sekutu. Soekarno dan Hatta pun bergegas memproklamasikan kemerdekaan Indonesia yang didukung oleh pemuda
Indonesia pada saat itu. Seperti yang terdapat dalam kutipan berikut.

"Kesempatan untuk kemerdekaan Indonesiaa muncul ketika bom atom Sekutu menghancurkan kota-kota Hiroshima dan Nagasiaki di Jepang pada 7 dan 9 Agustus 1945". (Wicaksana, 2018:55)

"Ditengah situasi ini akhirnya Soekarno dan Hatta memproklamasikan kemerdekaan Indonesia pada 17 Agustus 1945". (Wicaksana, 2018:55)

Setelah menunaikan tugas yang amat penting bagi seluruh rakyat Indonesia, Soekarno dan Hatta dipercaya sebagai Presiden dan Wakil Presiden oleh rakyat Indonesia. Seperti yang terdapat dalam kutipan berikut.

"Keesokan harinya Soekarno dan Hatta dipilih sebagai Presiden dan Wakil Presiden Rl”. (Wicaksana,

Sebelum dan setelah menjadi Wakil Presiden, Hatta tetap menjaga Indonesia dan mempertahankan kesatuan dan persatuan Republik Indonesia. Seperti yang terdapat dalam kutipan berikut.

"Selama menjadi Wakil Presiden, Hatta sangat menyelamatkan Republik Indonesia. la mempertahankan naskah perjanjian Linggarjati di Sidang Pleno KNIP (Komite Nasional Indonesia Pusat) di Malang, Jawa Timur, pada 25 Februari - 6 Maret 1947". (Wicaksana, 2018:60)

Gejolak politik tidak hanya terjadi dalam diri Hatta saja. Bahkan, dengan rekan seperjuannya Soekarno, Hatta memiliki perbedaan pandangan politik. Seperti yang terdapat dalam beberapa kutipan berikut.

"Dalam berpolitik, Mohammad Hatta beberapa kali berbeda pendapat dengan Soekarno". (Wicaksana, 2018:76) 
"Peristiwa puncak yang menandai retaknya Hatta dan Soekarno terjadi ketika Hatta mengundurkan diri dari jabatan Wakil Presiden RI pada 1 Desember 1956". (Wicaksana, 2018:76)

Mengundurkan diri sebagai Wakil Presiden pada saat itu adalah keputusan final dari Hatta untuk menyudahi perbedaan dengan Soekarno. Pengaruh inilah yang kemudian memperlihatkan perbedaan pandangan dan tindakan mereka dalam praktek politik (Indriyanto, 2007).

Beberapa kutipan di atas yang terdapat dalam buku Mohammad Hatta, menunjukkan struktur kedua teks biografi yakni, peristiwa dan masalah. Seperti Zabadi dan Sutejo (2013:42) yang mengatakan bahwa peristiwa dan masalah adalah bagian kejadian yang berisi penjelasan peristiwa-peristiwa yang dialami oleh tokoh termasuk masalah yang dihadapinya dalam mencapai cita-citanya. Jadi, dalam buku Mohammad Hatta ada struktur kedua teks biografi yakni, peristiwa dan masalah

Reorientasi adalah pandangan penulis terhadap tokoh yang diceritakan. Reorientasi pada buku Mohammad Hatta terdapat dalam beberapa $B A B$ yaitu, $B A B$, BAB 12, BAB 13, BAB 14, BAB 15, BAB 16, BAB 17, BAB 18, BAB 19, dan BAB 20. Hatta adalah sosok pemimpin yang tegas di mata rakyat Indonesia. la selalu menerapkan Pancasila dalam tiap jengkal hidupnya. Seperti yang terdapat dalam beberapa kutipan berikut.

"Hatta adalah sosok pemimpin yang
menerapkan Pancasila dalam
kehidupannya sehari-hari".
(Wicaksana, 2018:104)

la tidak pernah lupa menjalankan syariat Islam dalam hidupnya. Seperti yang terdapat pada kutipan berikut.

"Hatta adalah orang yang taat menjalankan syariat Islam dalam kehidupannya

(Wicaksana, 2018:107)

sehari-hari”.

Dengan kecerdasan yang ia miliki, Hatta mampu menjadi sosok penting dalam perjuangan Indonesia. Bahkan Hatta hampir ada di setiap kegiatan penting bangsa Indonesia. Seperti yang terdapat pada kutipan berikut.

"Hatta memiliki wawasan intelektual yang luas dan visioner". (Wicaksana, 2018:123)

Bagi Hatta bagaimana pun keadaannya menulis adalah panggilan jiwa (Wicaksana, 2018:167). Seperti yang terdapat pada beberapa kutipan berikut.

"Di masa pergerakan nasional Hatta adalah salah satu aktivis perjuangan kemerdekaan yang paling banyak menulis". (Wicaksana, 2018:167)

Dari sekian banyak cerita kehidupan Hatta yang Pancasilais, Nasionalis, dan penuh dengan kedisiplinan, Hatta juga punya beberapa cerita unik dan lucu. Seperti yang terdapat pada beberapa kutipan berikut.

"Ada cerita lain dari Hatta, yaitu soal hobinya memelihara kucing. Di mana pun ia berada, ntah di pengasingan atau di rumah sendiri, ia selalu punya kucing". (Wicaksana, 2018:186)

Cerita yang menyayat hati juga menyertai perjalanan hidup Hatta, ketika mengetahui salah seorang teman seperjuangannya Soekarno tengah terbaring sakit.

Setelah Soekarno berpulang, Hatta juga rajin keluar masuk rumah sakit. Sebanyak enam kali dirawat di rumah sakit, Hatta akhirnya menghembuskan nafas terkahir pada 14 Maret 1980. Seperti yang terdapat pada kutipan berikut.

"Hatta wafat pada 14 Maret 1980 jam 18.56 di Rumah Sakit Cipto Mangun Kusumo Jakarta setelah sebelas hari 
ia dirawat di sana....". (Wicaksana, 2018:198)

Untuk menghormati perjuangan Soekarno dan Hatta demi memerdekakan bangsa dan negara, pada 23 Oktober 1986, mereka diberikan gelar Pahlawan Proklamator. Lalu pada 7 November 2012 Hatta bersama Soekarno ditetapkan sebagai Pahlawan Nasional oleh Presiden Susilo Bambang Yudhoyono.

Jadi, kutipan-kutipan frase dan kalimat di atas menjelaskan reorientasi dalam buku Mohammad Hatta. Disebut reorientasi karena, jika ditelisik dari segi artinya, reorientasi berarti penyeritaan ulang secara singkat oleh penulis buku tentang tokoh yang diangkat dalam teks biografi.

Jadi, dapat disimpulkan dalam buku Mohammad Hatta ada struktur ketiga teks biografi yakni, reorientasi. Seperti dalam dalam buku teks siswa kelas $X$ kurikulum 2013 (2015:215) dijelaskan bahwa, reorientasi, berisi komentar evaluatif atau pernyataan simpulan mengenai rangkaian peristiwa yang telah diceritakan sebelumnya.

Untuk memahami sebuah teks biografi dan menulisnya, sebelumnya harus diketahui ciri kebahasaan teks biografi. Menurut Zabadi dan Sutejo (2013:45) kebahasaan teks biografi meliputi (1) kata kerja, (2) kata hubung, (3) rujukan kata, (4) peristiwa, waktu dan tempat, pada teks cerita biografi selalu disertai dengan adanya keterangan peristiwa, waktu dan tempat.

Kata kerja menjelaskan kegiatan atau tindakan yang dilakukan subjek sehingga tak heran bila kata kerja berfungsi sebagai predikat dalam suatu kalimat. Kata kerja aktif merupakan jenis kata kerja di mana subjeknya berposisi sebagai pelaku. Kata kerja ini biasanya memiliki imbuhan me- atau ber-. Berikut contoh kata kerja aktif yang terdapat dalam buku Mohammad Hatta.
"Sepulang sekolah, ia mengajak melayarkan kapal kecil itu di tebat kecil sebmbari menunggu jam mengaji di surau Syekh Djambek tiba". (Wicaksana, 2018:4)

"Mereka berdiskusi tentang otonomi bagi Hindia Belanda". (Wicaksana, 2018:20)

Berikutnya adalah kata kerja pasif. Kata kerja pasif adalah jenis kata kerja di mana subjeknya berposisi sebagai korban dari kata kerja tersebut. Berikut kata kerja pasif yang terdapat dalam buku Mohammad Hatta.

"Hatta ditangkap setelah dua polisi datang ke rumahnya....". (Wicaksana, 2018: 24)

"la dibawa ke penjara Casius-straat". (Wicaksana, 2018: 24)

"Setelah ditahan selama 5 bulan....". (Wicaksana, 2018: 24)

Tulisan yang bercetak tebal dalam kutipan di atas adalah sebagian kata kerja aktif dan pasif yang ada dalam buku Mohammad Hatta. Kata kerja adalah kata yang menyatakan tindakan, Ramlan (dalam Putrayasa, 2006:76). Kata kerja tersebut adalah kata kerja aktif dan pasif. Dalam buku Mohammad Hatta, ada banyak sekali kata kerja. Buku tersebut kaya akan diksi yang diharapkan mampu membantu siswa dalam menghadapi hambatan pada saat menulis teks biografi khususnya.

Kata hubung atau konjungsi adalah kata tugas yang menghubungkan dua klausa atau lebih. Seperti beberapa contoh kata hubung berikut.

"Athar adalah anak kedua bagi apasangan Mohammad Djamil dan Saleha". (Wicaksana, 2018:2)

"Kemudian Hatta dan Ayub kembali ke Indonesia pada awal Mei 1933". (Wicaksana, 2018:14) 
"Nelly adalah putri seorang sudagar kaya yang besar di Jakarta. Sedangkan Hatta....". (Wicaksana, 2018:15)

"Di Rotterdam, mula-mula Hatta menginap di rumah seorang kenalan. Setelah itu, seperti juga pelajar....". (Wicaksana, 2018:19)

"Soekarno dan Hatta diculik oleh para pemuda lalu dibawa ke sebuah rumah milik salah seorang pimpinan PETA....". (Wicaksana, 2018:55)

"Dalam jangka waktu lama, Indonesia hidup dalam bayangan feodalisme.Tetapi neofeodalisme....". (Wicaksana, 2018:84)

"la merasa khawatir dengan kemungkinan tersebut padahal kemerdekaan Indonesia harus berarti pula persatuan nasional. Oleh karena itulah ia mengususlkan....". (Wicaksana, 2018:101)

"Hatta selalu menekankan pentingnya nasionalisme dan Islam bagi masyarakat Indonesia. Namun demikian ia tidak mempersoalkan....". (Wicaksana, 2018:97)

"Menurut Hatta, semula rakyat tidak tahu cara melepaskan diri dari penindasan walaupun mereka....".(Wicaksana, 2018:126)

Kutipan di atas merupakan kata hubung. Kata hubung, biasa disebut dengan konjungsi. Kata penghubung berfungsi sebagai penghubung antara kata yang satu dengan kata yang lainnya. Berdasarkan hasil wawancara, diksi siswa dalam mengembangkan cerita masih sangat monoton, terutama dalam memilih kata hubung. Dalam buku Mohammad Hatta banyak contoh diksi yang dapat siswa pakai untuk mengembangkan ceritanya seperti kutipan di atas, sehingga siswa mampu menulis teks biografi yang baik dan benar.
Rujukan kata adalah bagian kata atau biasa disebut dengan kelompok kata yang merujuk pada kata-kata sebelumnya. Kata rujukan dan kalimat rujukan sangat berguna bagi estetika dalam berbahasa. Ada beberapa jenis kata rujukan, seperti kata rujukan benda, orang, dan tempat. Seperti kutipan di bawah ini.

Kata rujukan orang atau yang diperlakukan seperti orang merupakan kata ganti atau rujukan untuk orang atau sesuatu yang diperlakukan atau dianggap seperti orang. Kata rujukan macam ini terdiri dari dia, ia, mereka, beliau, dan lain sebagainya. Berikut contoh kalimat yang terdapat dalam buku Mohammad Hatta.

"Athar adalah anak kedua bagi pasangan Mohammad Djamil dan Saleha. Anak pertama mereka, Rafiah,..... (Wicaksana, 2018:2)

"Sejak berumur lima tahun, di siang hari Hatta belajar di Sekolah Melayu .... la menikmati masa kecilnya". (Wicaksana, 2018:3)

"Bung Tomo tokoh pemuda Surabaya, sudah melakukan hal itu. Dia berpidato yang disiarkan di radio....". (Wicaksana, 2018:81)

"Djamil Djambek, seorang ulama yang lahir pada tahun 1862, menerima murid di suraunya selepas....". (Wicaksana, 2018:3)

Kata rujukan yang digunakan untuk merujuk kepada benda atau sesuatu hal terdiri dari kata ini, itu, dan tersebut. Berikut contoh kalimat yang terdapat dalam buku Mohammad Hatta.

"Pada tahun 1913, Hatta melanjutkan pendidikan ke MULO (Meer Uitgebreid Lagere Onderwijs) di Padang. Di kota ini ia....". (Wicaksana, 2018:6)

"Suatu sore di akhir Agustus 1919, Hatta mendatangi kantor Ayub di kawasan Patekoan. Saat itulah Ayub 
menyatakan akan membiayai Hatta selama di Jakarta". (Wicaksana, 2018:10)

"Tentara Republik Indonesia bergerak ke gunung-gunung untuk melakukan perlawanan secara bergrilya. Panglima Besar TNI Jendral Sudirman yang sedang sakit pun memimpin perang gerilya tersebut". (Wicaksana, 2018:70)

Secara sederhana, kata rujukan tempat merupakan kata ganti atau acuan kepada suatu tempat. Beberapa kata yang kerap digunakan sebagai kata rujukan tempat ialah di sini, di situ, di sana, dan lain sebagainya. Berikut contoh kata rujukan tempat yang terdapat pada kutipan dalam buku Mohammad Hatta.

"Belanda memang punya hubungan unik dengan Hatta. Hatta menghabiskan sebagian hidupnya di sana". (Wicaksana, 2018:17)

"Djamil Djambek, seorang ulama yang lahir pada tahun 1862, menerima murid di suraunya selepas belajar ilmu falak di Mekah. Di sinilah Hatta belajar mengaji”. (Wicaksana, 2018:3)

Beberapa kutipan di atas adalah contoh kata atau kalimat yang menunjukkan kata rujukan dalam buku Mohammad Hatta. Siswa harus memahami unsur atau ciri kebahasaan teks biografi yang terdapat dalam buku tersebut. Siswa juga diharapkan terbantu dalam menulis teks biografi, karena setiap teks memiliki cirinya masing-masing.

Peneliti juga menganggap bahwa menulis teks biografi penting dikuasai oleh siswa, karena selain diharapkan untuk memahami teks biografi, siswa nantinya harus dapat menyusun/menulis teks biografi secara mandiri sesuai dengan informasi yang didapat dari berbagai sumber tentang tokoh yang di tulis biografinya.
Peristiwa, waktu dan tempat, pada teks cerita biografi selalu disertai dengan adanya keterangan peristiwa, waktu dan tempat. Adanya keterangan peristiwa, waktu dan tempat guna untuk memperjelas dalam suatu kalimat tersebut. Kebahasaan teks biografi tersebut merupakan ciri utama atau pembeda di antara teks-teks lainnya. Berikut contohnya.

"Pada 12 Agustus 1920, disebuah rumah kayu bertingkat dua di Desa Aur Tajungkang, Bukit Tinggi, pasangan suami istri sedang berbahagia". (Wicaksana, 2018:1)

"Pada tahun 1908, sejumlah serdadu marsose ditempatkan di jembatan batu dekat rumah Hatta di Aur Tajungkang". (Wicaksana, 2018:4)

Tulisan yang bercetak tebal dari beberapa kutipan di atas adalah contoh frase/kalimat yang menunjukkan kata peristiwa, waktu, dan tempat. Kata atau kalimat tersebut menjadi ciri pembeda teks biografi dengan teks lainnya. Siswa diharapkan mampu memahami hal tersebut agar dapat menulis teks biografi yang baik dan benar.

Jadi, dalam buku Mohammad Hatta terdapat ciri kebahasaan teks biografi, meliputi, kata kerja, kata hubung atau kunjungsi, kata rujukan, dan kata peristiwa, waktu, dan tempat. Sehingga, buku tersebut dapat dikatakan layak untuk dijadikan model dalam pembelajaran menulis teks biografi di SMA, karena sudah memenuhi syarat kebahasaan dari sebuah teks biografi.

Pembelajaran teks biografi kelas $X$ diselenggarakan untuk mencapai 4 kompetensi. Yang pertama adalah kompetensi dasar 3.14 yang berbunyi, menganalisis butir-butir penting yang dapat diteladani dari teks biografi berkaitan dengan bidang pekerjaan. Yang kedua adalah kompetensi dasar 4.14 yang berbunyi, menyajikan hal-hal yang dapat diteladani dari tokoh yang terdapat dalam teks biografi berkaitan dengan bidang 
pekerjaan yang dibaca secara tertulis. Yang ketiga adalah kompetensi dasar 3.15 yang berbunyi, menganalisis aspek makna dan kebahasaan dalam teks biografi berkaitan dengan bidang pekerjaan. Yang keempat adalah kompetensi dasar 4.15 yang berbunyi, membuat teks biografi berkaitan dengan bidang pekerjaan baik lisan maupun tulis. Untuk memenuhi kompetensi dasar 3.14, dalam buku Mohammad Hatta sudah ada butir-butir penting yang dapat dianalisis dan diteladanin oleh peserta didik yang berkaitan dengan bidang pekerjaan. Contohnya pada struktur peristiwa dan masalah yang terdapat dalam buku Mohammad Hatta di BAB 1 hingga BAB 10. Pada bab-bab tersebut banyak terdapat butir-butir penting yang dapat dianalisis dan diteladani.

Untuk memenuhi kompetensi dasar 4.14, materi yang diperlukan adalah kejadian-kejadian penting yang dialami tokoh semasa hidupnya, seperti pendidikan, prestasi, dan perjalanan karirnya. Dalam buku Mohammad Hatta, tentu semua itu ada, khususnya pada $B A B 1$ hingga $B A B$ 10.

Selanjutnya, untuk memenuhi pada kompetensi dasar 3.15, materi yang diperlukan adalah ciri kebahasaan teks biografi. Materi tersebut ada dalam buku Mohammad Hatta. Contohnya kebahasaan teks biografi Mohammad Hatta meliputi (1) kata kerja, (2) kata hubung atau konjungsi, (3) rujukan kata, serta, (4) peristiwa, waktu dan tempat.

Untuk memenuhi kompetensi dasar 4.15 , sebelumnya siswa harus memahami struktur dan kebahasaan teks biografi. Materi yang diperlukan adalah struktur dan kebahasaan teks biografi. Semua materi tersebut ada dalam buku Mohammad Hatta. Contohnya seperti berikut. Struktur atau bagian teks biografi menurut Zabadi dan Sutejo (2013:42), dibagi menjadi tiga yaitu orientasi, peristiwa dan masalah, dan reorientasi.
(1) Orientasi atau bagian pengenalan adalah gambaran awal tentang tokoh atau pelaku di dalam teks biografi. Berikut contoh orientasi dari teks biografi Mohammad Hatta "Pada 12 Agustus 1902, di sebuah rumah kayu bertingkat dua di Desa Aur Tajungkang, Bukit Tinggi, pasangan suami istri sedang berbahagia. Sang istri, Siti Saleha, melahirkan seorang bayi laki-laki yang kemudian dinamai Muhammad Athar. Nama Athar berasal dari Bahasa Arab, yang berarti "harum". Kelak kita mengenal namanya sebagai Mohammad Hatta".

(2) Peristiwa dan masalah adalah bagian kejadian yang berisi penjelasan peristiwa-peristiwa yang dialami oleh tokoh termasuk masalah yang dihadapinya dalam mencapai cita-citanya. Selain itu, bagian ini juga berisi hal-hal yang menarik, mengesankan, dan mengagumkan yang diuraikan dalam bagian peristiwa. Berikut contoh peristiwa dan masalah, "Pada Januari 1935 Hatta diasingkan ke Boven Digul di Papua. Hatta sendiri sempat menulis sebuah renungan bahwa dirinya sangat menyadari betapa ia menghadapi konsekuensi serius akibat aktivitas polotiknya".

Struktur yang terakhir (3) Reorientasi adalah pandangan penulis terhadap tokoh yang diceritakan. Berikut contoh reorientasi "Ada banyak kisah unik mengenai sosok Hatta. Cerita-cerita itu dapat membuat kita tersenyum saat mendengarnya. Hatta adalah sosok yang tidak bisa dibungkam. Hatta akan terus bersuara melalui tulisan-tulisannya".

Kebahasaan teks biografi meliputi (1) kata kerja, setiap teks naratif, seperti teks biografi selalu terdapat kata kerja yang menyatakan tindakan (2) kata hubung, kata hubung biasa disebut dengan konjungsi. Kata penghubung berfungsi sebagai penghubung antara kata yang satu dengan kata yang lainnya. Kata hubung dibedakan menjadi dua, yaitu; kata hubung antar kalimat dan kata hubung intrakalimat, (3) rujukan kata, kata rujukan adalah bagian 
kata atau biasa disebut dengan kelompok kata yang merujuk pada kata-kata sebelumnya, serta (4) peristiwa, waktu dan tempat, pada teks cerita biografi selalu disertai dengan adanya keterangan aktivitas, waktu dan tempat. Adanya keterangan aktivitas, waktu dan tempat guna untuk memperjelas dalam suatu kalimat tersebut.

Berdasarkan uraian di atas buku Mohammad Hatta memiliki relevansi dengan kompetensi dasar, indikator, tujuan pembelajaran serta fokus nilai sikap dalam RPP menulis teks biografi. Melihat hal tersebut, maka cerita ini berkaitan dengan pembelajaran menulis teks biografi kelas $X$ kurikulum 2013. Oleh karena itu, buku Mohammad Hatta memiliki relevansi terhadap pembelajaran menulis teks biografi kurikulum 2013.

Penelitian ini berimplikasi membuka peluang dalam penelitian sebuah teks, khususnya penelitian struktur dan kebahasaan buku. Selain itu, melalui penelitian ini akan terbuka jalan bagi upayaupaya menggalakkan kegiatan menulis, baik melalui sekolah (formal), pelatihan atau kursus (nonformal), serta keluarga dan lingkungan (informal). Oleh karena penelitian ini menghubungkan teks dan pendidikan, maka ini dapat berimplikasi pula dalam membuka wawasan guru untuk lebih kreatif dalam pemilihan media atau bahan ajar untuk pembelajaran di sekolah.

\section{SIMPULAN DAN SARAN}

Ada beberapa hal yang menjadi simpulan dalam penelitian ini. Dari segi isi, buku Mohammad Hatta mengandung keseluruhan stuktur teks biografi meliputi, orientasi, peristiwa dan masalah, serta reorientasi. Buku Mohammad Hatta juga mengandung kebahasaan teks biografi meliputi, kata kerja, rujukan kata, kata hubung serta kata yang menunjukkan peristiwa, waktu, dan tempat. Sehingga dapat dikatakan bahwa buku Mohammad Hatta cocok untuk dijadikan bahan ajar menulis teks biografi karena telah memenuhi syarat sebuah teks biografi.

Berdasarkan temuan-temuan dalam penelitian ini, terdapat beberapa saran yang dapat disampaikan. Bagi guru, penelitian ini diharapkan dapat memberikan motivasi kepada guru untuk menambah referensi dalam pemilihan bahan bacaan untuk pembelajaran menulis teks biografi di sekolah. Kedua, pemerintah hendaknya memperbanyak penerbitan buku biografi tokoh-tokoh penting khususnya tokoh penting Indonesia. Ketiga, penelitian lainnya diharapkan mengkaji buku-buku atau teks-teks biografi lainnya, sebagai acuan dalam meneliti sebuah teks, buku, atau mata pelajaran lainnya yang sejenis dengan penelitian ini.

\section{DAFTAR PUSTAKA}

Fuad, Zulfikar. 2012. The Secret Of Biography:Rahasia Menulis Biografi Ala Ramadhan K.H. Jakarta: Akademia Permata

Kemendikbud RI. 2013. Permendikbud RI Nomor 69 tahun 2013 tentang Kerangka Dasar dan Struktur Kulikulum SMA/MA. Jakarta.

Mahsun. 2014. Teks dalam Pembelajaran Bahasa Indonesia Kurikulum 2013. Jakarta: Rajagrafindo Persada.

Nidan. 2015. Resensi buku Mohammad Hatta karya Anom Whani Wicaksana. Tersedia pada http://nidaanksabil.blogspot.com/201 7/01/resensi-rekam-jejak-sangbapak-bangsa.html nidan (diakses pada tanggal 7 Januari 2019)

Pusat Kurikulum dan Perbukuan, Balitbang, Kemdikbud. 2015. Buku Teks Siswa Bahasa Indonesia Kelas X.pdf. Diunduh pada tanggal 25 Desember 2018. 
Volume : 9 Nomor: 2, Agustus 2019

P-ISSN : 2614-4743 (cetak) dan e-ISSN : 2614-2007 (online)

Priyatni, Endah Tri. 2014. Desain Pembelajaran Bahasa Indonesia dalam Kurikulum 2013. Jakarta: Bumi Aksara.

Sukirno. 2016. Belajar Cepat Menulis Kreatif Berbasis Kuantum. Yogyakarta: Pustaka Pelajar.

Tarigan, Henry Guntur. 2008. Menulis sebagai Suatu Keterampilan Bahasa. Bandung: Angkasa Bandung.

Zabadi, Fairul dan Sutejo. 2013. Bahasa Indonesia Wahana Pengetahuan. Jakarta: Kementrian Pendidikan dan Kebudayaan. 